\title{
First occurrence of the Kentish Snail Monacha cantiana (Mollusca: Gastropoda: Hygromiidae) in the Czech Republic
}

\author{
Jaroslav Č. HlaváČ $\check{C}^{1,2} \&$ Alena Peltanová 3,4 \\ ${ }^{1}$ National Museum in Prague, Zoological Department, Václavské náměstí 68, CZ-11579, Prague 1, e-mail: jaroslav_hlavac@nm.cz \\ ${ }^{2}$ Institute of Geology AS CR, v.v.i, Laboratory of Environmental Geology and Geochemistry, Rozvojová 269, CZ-16500 Prague 6 \\ - Lysolaje, e-mail: jhlavac@gli.cas.cz \\ ${ }^{3}$ Department of Ecology, Faculty of Science, Charles University in Prague, Viničná 7, CZ-12844, Prague 2 \\ ${ }^{4}$ The Silva Tarouca Research Institute for Landscape and Ornamental Gardening, Květnové náměstí 391, CZ-25243, Prühonice, \\ e-mail: alena.peltanova@centrum.cz
}

\begin{abstract}
Hlaváč J.Č. \& Peltanová A., 2010: First occurrence of the Kentish Snail Monacha cantiana (Mollusca: Gastropoda: Hygromiidae) in the Czech Republic. - Malacologica Bohemoslovaca, 9: 11-15. Online serial at $<$ http:// mollusca.sav.sk> 8-June-2010.

We document the first occurrence of the Kentish Snail Monacha cantiana (Montagu, 1803) from Prague, Czech Republic. During autumn 2009, an abundant population of M. cantiana was found at sites with suitable vegetation and microclimatic conditions, predominantly composed of grassy vegetation cover. It is expected that this species will continue to spread in the Czech Republic.
\end{abstract}

Key words: Monacha cantiana, Hygromiidae, first record, distribution, Czech Republic, introduction

\section{Introduction}

The Kentish Snail, Monacha cantiana (Montagu, 1803) is a terrestrial gastropod (Pulmonata: Hygromiidae) with a western Mediterranean and northwest European distribution, originally inhabiting Italy and southern France (MANGANELLi et al. 2005). The species has spread into Northern France, Belgium, the Netherlands and northern Germany, and then to Great Britain in Late Roman times, expanded there mainly during the Middle Ages, and continued to spread, with Ireland being a notable exception (KERNEY et al. 1983). During the last 50 years, $M$. cantiana has been found in the surroundings of Vienna, Austria (FISCHER \& DudA 2004).

The shell of $M$. cantiana is creamy white coloured, with 5-6 slightly convex whorls, and a variable width of 11$20 \mathrm{~mm}$. The shell is larger than the shell of the congeneric xerophilous Carthusian Snail, Monacha cartusiana (O.F. Müller, 1774), that has previously been reported from the Czech Republic (Hudec 1954, JuŘIČKOVÁ 1998, KolOuCH 2005, LožEK 1956, 1999, MAŇAs 2002, NovÁK \& NovÁK 2009, Pech \& Pechová 2009, Urbánek 1968). The shell of $M$. cantiana has a white or reddish internal lip with much less contrast than the shell of M. cartusiana which has a "white strip" on the external shell side. Another distinct character between the shells of $M$. cantiana and $M$. cartusiana is the shape of the umbilicus. The umbilicus of M. cantiana is wider and more open (Fig. 2) than the umbilicus of $M$. cartusiana which is narrow and for two thirds obscured (Table 1). Both species are relatively variable in shell characters (Table 1), significant differences are present on reproductive tract (Fig. 3): M. cartusiana has wider base of vaginal appendix. GERMAin (1930) use term "appendice bilobe du vagin" for this structure with 2 spherical lobes, Grossu (1983) presents only one "lobe" - bottle looking vaginal appendix. M.cantiana has only thin simple vaginal appendix with no other lobes (GERMAIN 1930). M. cantiana predominantly inhabits the herbal layer of hedges, waste grounds, scrublands, roadsides and railways, and prefers grassy habitats on dry calcareous soils (FeChTER \& FALKNer 1990).

Field observations on the life-cycle of $M$. cantiana were published by CHATFIELD (1968) from Bershire, southeastern England, UK, as follows: $M$. cantiana has more than one generation per year, but most adults have only one breeding season during their 12-18 month-long life history. Juvenile stages occur mainly during autumn and winter, with feeding activity at or below $0^{\circ} \mathrm{C}$. In periods of prolonged frost they hibernate at the ground level. Mating usually occurs from May to September, and egg-laying from May to October (or even to mid-November). The majority of eggs

Table 1. Basic conchological characteristics of Monacha cantiana and M. cartusiana.

\begin{tabular}{|l|l|l|}
\hline Characterictics & Monacha cantiana (Montagu, 1803) & Monacha cartusiana (O.F. Müller, 1774) \\
\hline Shell diameter & variable $11-20 \mathrm{~mm}$ & extremly variable 6-18 mm \\
\hline Aperture & creamy white (as whole shell) or brown & brown (adult) \\
\hline Internal lip ("white stripe") & white or reddish & white \\
\hline Umbilicus & wider and open & narrow and 2/3 obscured \\
\hline
\end{tabular}




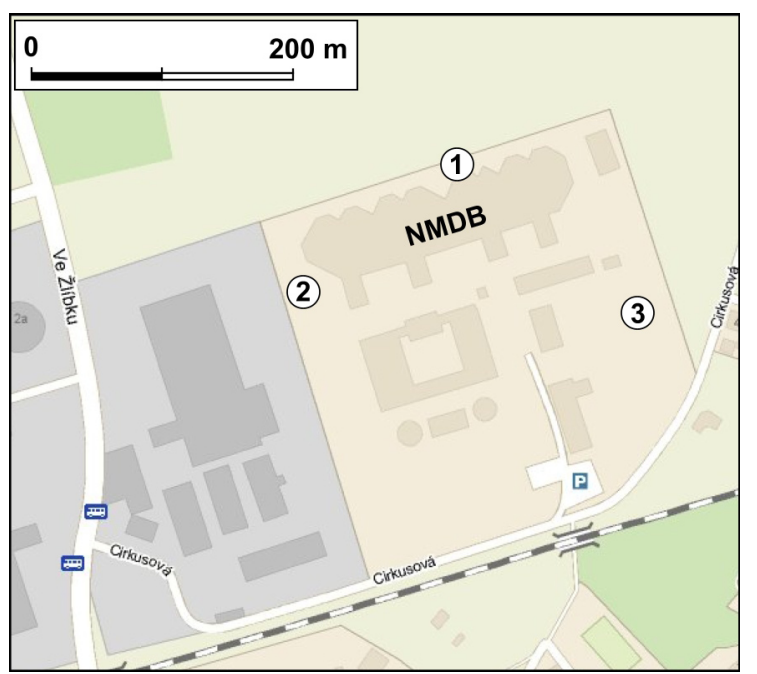

Fig. 1. Location of Monacha cantiana in the area of the National Museum depositary buildings (NMDB), Horní Počernice, Prague. Site $1-50^{\circ} 07^{\prime} 21.72^{\prime \prime N}, 14^{\circ} 37^{\prime} 44.16^{\prime \prime} E$; Site $2-50^{\circ} 07^{\prime} 18.83^{\prime \prime N}$, $14^{\circ} 37^{\prime} 37.59^{\prime \prime E}$; Site $3-50^{\circ} 07^{\prime} 18.65^{\prime \prime N}, 14^{\circ} 37^{\prime} 50.65^{\prime \prime E}$.

are found during autumn months. Hatching was observed about 14-20 days after egg-laying. The shells of newly hatched juveniles and very young individuals are covered with periostracal hair, while adults mainly have only rows. Daily activity of $M$. cantiana has been observed during the late evenings or early mornings.

\section{Material and methods}

The new Czech locality is situated in Prague, the Horní Počernice district, in the area of the National Museum depositary buildings (NMDB). Material was collected during September and October 2009 at three isolated sites (Fig. 1):

Site $1-50^{\circ} 07^{\prime} 21.72^{\prime \prime} \mathrm{N}, 14^{\circ} 37^{\prime} 44.16^{\prime \prime} \mathrm{E}, 265 \mathrm{~m}$ a.s.l., 2 Sep 2009 - 1 living ex., 5 Oct 2009 - many living ex., 21 Oct
2009 - many living ex., J. Hlaváč lgt.

Site $2-50^{\circ} 07^{\prime} 18.83^{\prime \prime} \mathrm{N}, 14^{\circ} 37^{\prime} 37.59^{\prime \prime} \mathrm{E}, 265 \mathrm{~m}$ a.s.1., 5 and 21 Oct 2009 - many living ex. on both dates, J. Hlaváč lgt.

Site $3-50^{\circ} 07^{\prime} 18.65^{\prime \prime N}, 14^{\circ} 37^{\prime} 50.65^{\prime \prime E}, 265 \mathrm{~m}$ a.s.l., 21 Oct 2009 - many living ex., J. Hlaváč lgt.

Snails were obtained by hand-collecting, and some living specimens were dissected (Fig. 3). Samples (shells and dissected bodies) are deposited in the National Museum in Prague, NMDB Horní Počernice, malacological collection, labelled as NM P6p-183/2009.

A botanical inventory of the sites was made on 21 Oct 2009 by botanist J. Šašek (Prague).

\section{Results}

The Kentish Snail M. cantiana was found at the three sites (Fig. 1), with species identification verified by conchological characters and dissection of genitalia (Figs 2, 3). The sites can be characterized as grassy patches, grassy edges and semi-mowed patchy grassy and shrubby covers along the roads and buildings in the area. The vegetation cover was dominated by grassy weeds (Arrhenatherum sp., Calamagrostis sp., Dactylis sp., Festuca sp., Lolium sp., Phleum sp., Poa sp.), followed by semi-ruderal and invasive herbs, and with sporadic occurrence of some shrubs and trees on the margins (Table 2, Figs 4, 5). These vegetation conditions were reflected in the molluscan composition documented at the studied sites. In addition to $M$. cantiana, other species were recorded such as Cochlicopa lubrica (O.F. Müller, 1774), Oxychilus draparnaudi (Beck, 1837), Arion lusitanicus Mabille, 1868, Deroceras reticulatum (O.F. Müller, 1774), M. cartusiana (O.F. Müller, 1774), Trochulus hispidus (Linnaeus, 1758), Xerolenta obvia (Menke, 1828), Cepaea hortensis (O.F. Müller, 1774), and Helix pomatia Linnaeus, 1758. The malacocoenoses are composed of common snails with some invasive or

Table 2. List of plant species identified at the whole locality with the occurrence of Monacha cantiana. J. Šašek, det., 21 Oct 2009.

\begin{tabular}{|c|c|c|}
\hline \multicolumn{3}{|l|}{ Plant species } \\
\hline Acer platanoides & Elymus (Agropyron) repens & Poa angustifolia \\
\hline Achillea millefolium & Epilobium sp. & Populus nigra var. italica \\
\hline Arenaria serpyllifolia & Festuca brevipila & Potentilla argentea \\
\hline Arrhenatherum elatius & Festuca rubra agg. & Potentilla reptans \\
\hline Artemisia vulgaris & Fraxinus excelsior & Prunus avium \\
\hline Aster sp. (cf. novi-belgii) & Galium mollugo & Rosa sp. \\
\hline Betula pendula & Geum urbanum & Rubus sp. \\
\hline Calamagrostis epigeios & Heracleum sphondylium & Sambucus nigra \\
\hline Centaurea jacea & Hypericum perforatum & Silene vulgaris \\
\hline Cerastium arvense & Leontodon hispidus & Solidago canadensis \\
\hline Cirsium arvense & Lolium perenne & Taraxacum sect. ruderalia \\
\hline Cirsium vulgare & Lotus corniculatus & Trifolium campestre \\
\hline Cornus sericea & Malus domestica & Trifolium pratense \\
\hline Crataegus sp. & Medicago falcata & Trifolium repens \\
\hline Dactylis glomerata & Pastinaca sativa & Urtica dioica \\
\hline Daucus carota & Phleum pratense & Veronica chamaedrys \\
\hline Echium vulgare & Plantago lanceolata & \\
\hline
\end{tabular}


modern immigrant species occurring mainly in urban areas, ruderal and semi-ruderal habitats and similar secondary ones throughout the Czech Republic. Populations of Monacha cantiana are very abundant at all sites and reflect the suitable vegetation and microclimatic conditions.
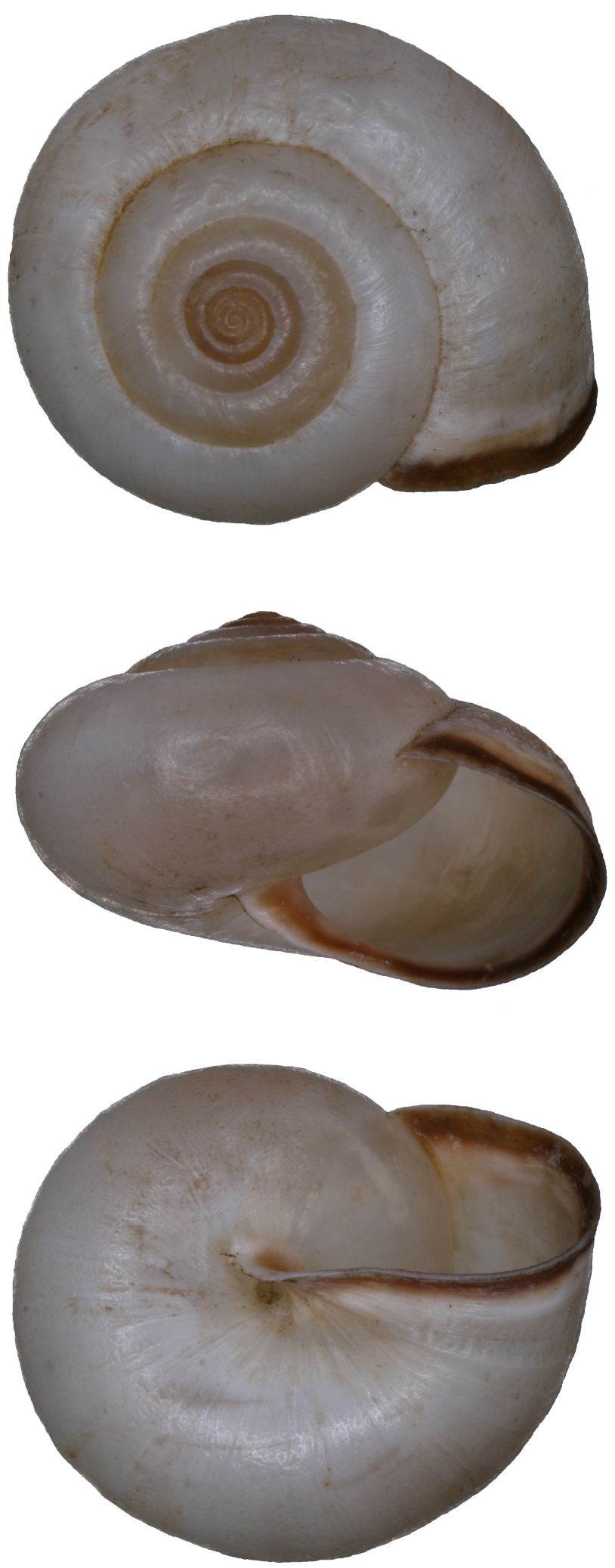

Fig. 2. Shell of Monacha cantiana from site no. 1 (Fig. 1). J. Hlaváč lgt., 5 Oct 2009. Width: $17.5 \mathrm{~mm}$, height: $11.5 \mathrm{~mm}$. (Photo: M. Horsák)
Abundances were about tens of individuals per $5 \mathrm{~m}^{2}$ on the grassy cover, while only few individuals were found at the margins of the three sites (approximately 1-5 individuals per $\left.5 \mathrm{~m}^{2}\right)$.

\section{Discussion}

Many terrestrial invertebrate species with originally Atlantic or Mediterranean distribution have been spreading north during the past few decades. The number of reports on non-indigenous species is significantly increasing, the boundaries of original species ranges are shifting and the composition of the Central European fauna is markedly changing (RoQues et al. 2009).

The first occurrence of Monacha cantiana documented here is problematic concerning the timing of the actual arrival of this snail to Prague. The studied population of $M$. cantiana is very abundant, with tens of individuals per $5 \mathrm{~m}^{2}$ at the three sites, and we thus expect that this population has been established at the locality for at least two years. No malacological investigations have been carried out in this district during the last 15 years. During this time, the NMDB was under construction and the landscaping of the surrounding terrain was finished in 2001-2002. Thus, the actual time of arrival of the first individuals of
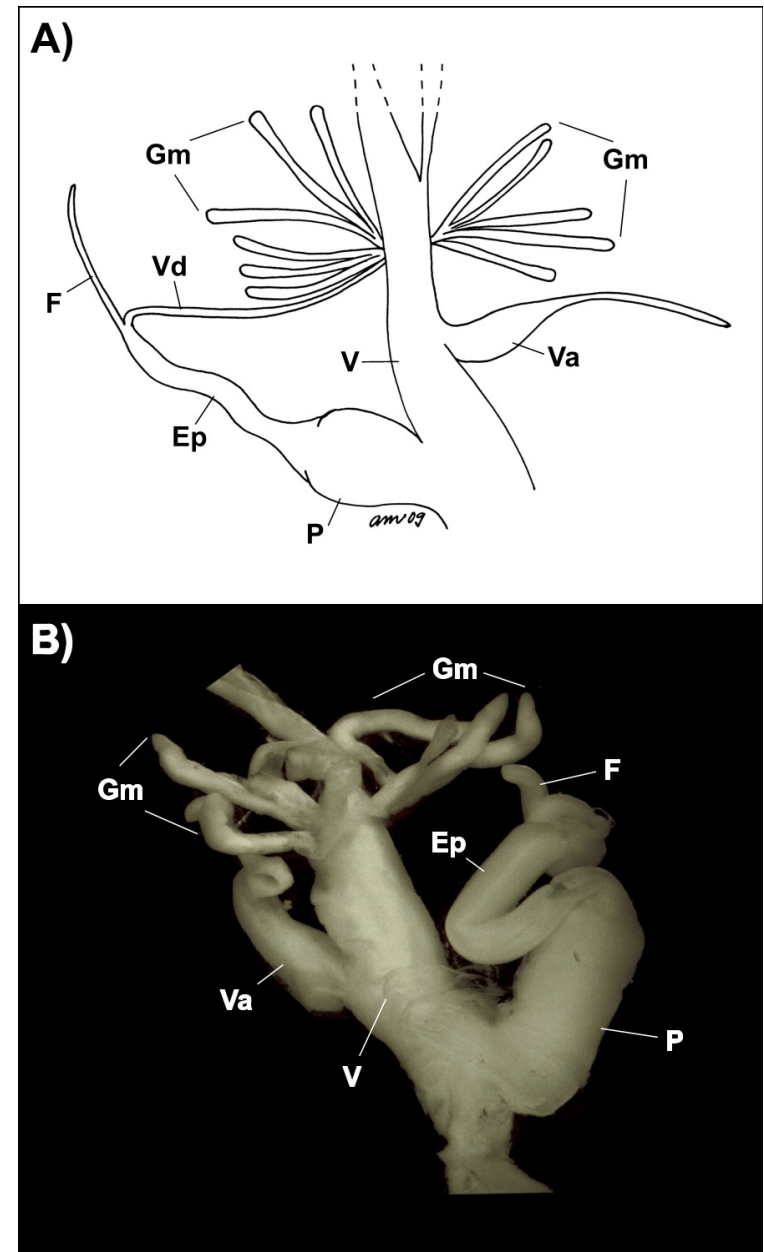

Fig. 3. Monacha cantiana, drawing (A) and photo (B) of genitalia. Site no. 1 (Fig. 1). A. Peltanová, dissect. Abbreviations: Ep - epiphallus, F - flagellum, Gm - mucous glands (glandulae mucosae), $\mathrm{P}$ - penis, $\mathrm{V}$ - vagina, $\mathrm{Va}$ - vaginal appendix, $\mathrm{Vd}$ - vas deferens. (Drawing and photo: A. Peltanová) 


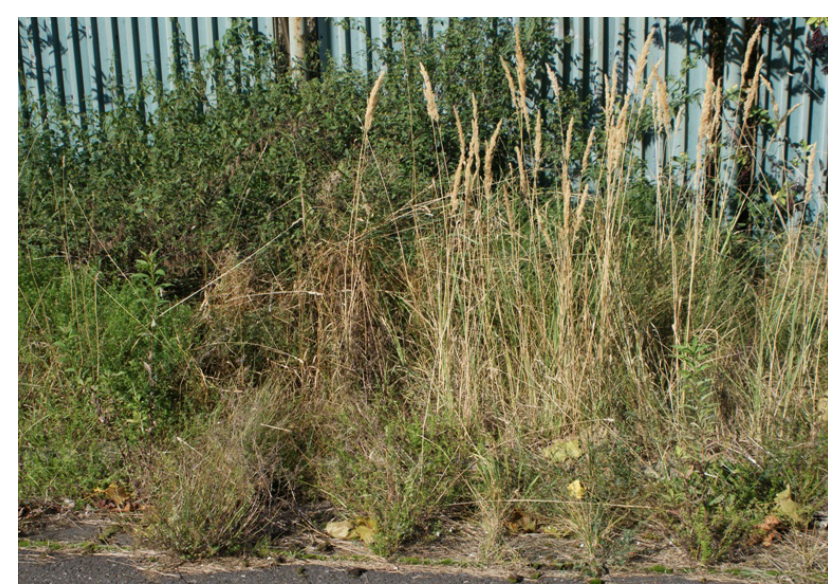

Fig. 4. Site 1, detailed view of the vegetation cover. (Photo: A. Peltanová)

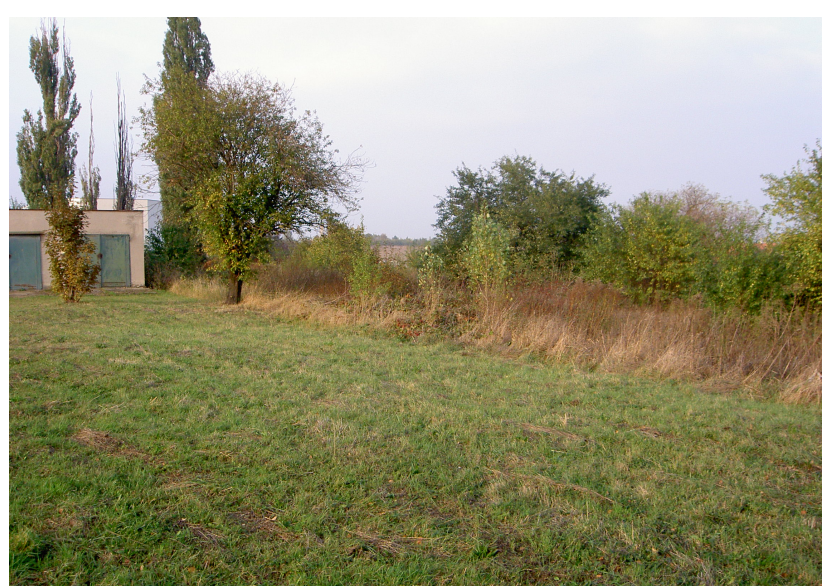

Fig. 5. Site 3, general view. (Photo: J. Hlaváč)

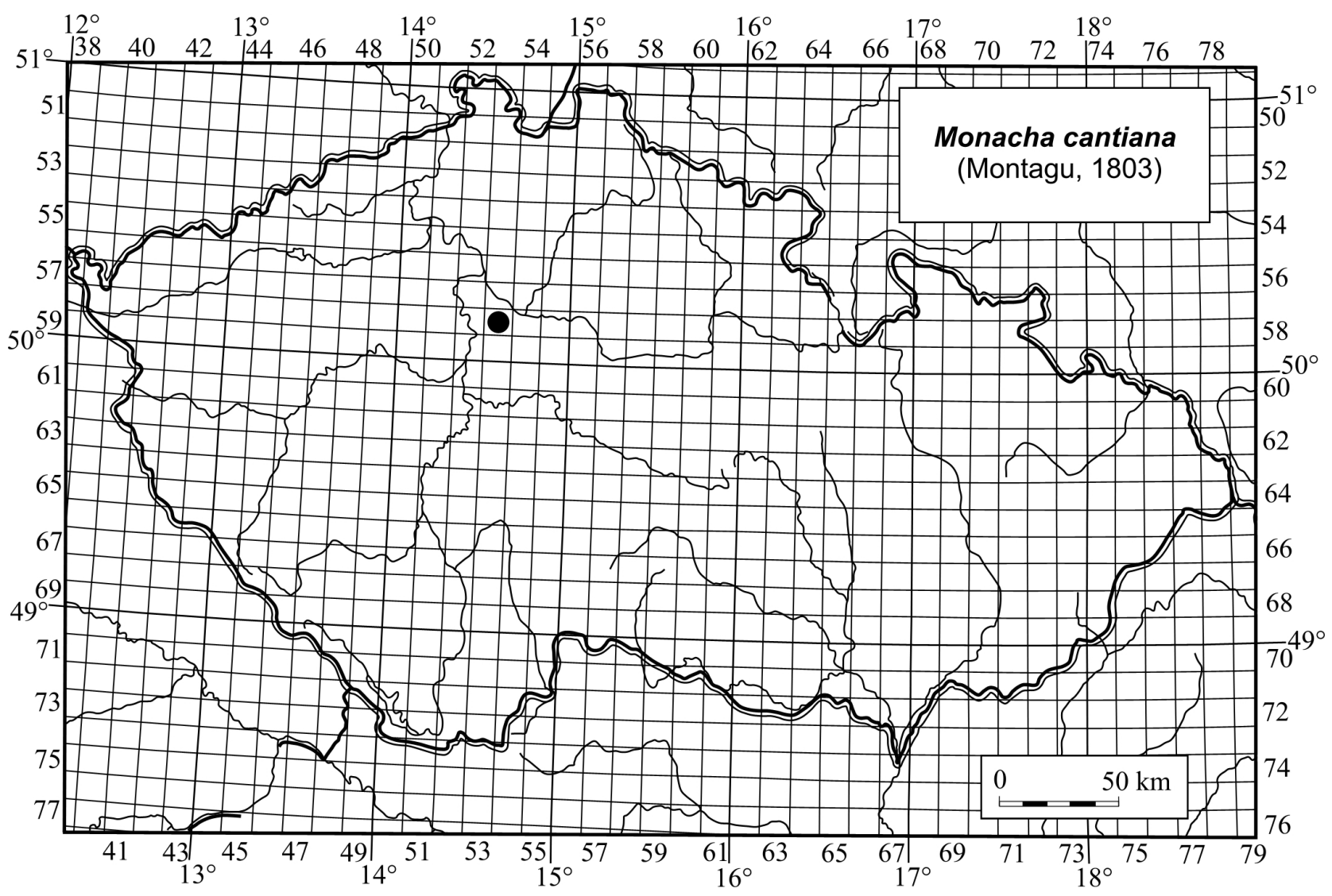

Fig. 6. Distribution of Monacha cantiana in the Czech Republic.

this species was likely even older.

The results of land snail distribution studies are consistent: with the help of increased transportation networks, species spreading has become faster (BENKE \& ReNKer 2005, AuBRY et al. 2006). The locality of $M$. cantiana reported here is situated on the northeast border of Prague in the Horní Počernice district (Figs 1,6). This area has many storage areas and trucking distribution centres, and a railway line which runs close to the NMDB. We therefore suppose that the origin of M. cantiana in Prague was due to transportation by train or truck. At the locality, M. cantiana is accompanied by several other snail species, such as Arion lusitanicus Mabille, Oxychilus draparnaudi (Beck), and M. cartusiana (Müller), which are categorized as invasive or non-native species in the Czech Republic. This type of enrichment of the Czech malacofauna by invasive or non- native species is expected (JUŘIČKOVÁ 2006), and was recently demonstrated by the occurrence of Cornu aspersum (Müller), a species native to the Mediterranean region, in Prague in 2008 and 2009 (JuŘıčKOvÁ \& KAPOUNEK 2009). The life history and cycle of $M$. cantiana is very similar to that of M. cartusiana, which is successfully spreading over the warm and intermediate climate regions of Bohemia, Moravia and Silesia (Míkovcová \& JuŘıǏ̌Ková 2008). Over the next few years, we will probably discover more populations of M. cantiana living in the Czech Republic. The nearest reported occurrences of M. cantiana in Europe are to the northwest (Saxony-Anhalt, Germany) (LiLL 2002) and southeast (the surroundings of Vienna, Austria) (FISCHER \& DuDA 2004). In the near future, we hope that molecular analyses could shed more light on the question of the origin of the first Czech population of M. cantiana. 


\section{Conclusion}

The Kentish Snail, Monacha cantiana (Montagu, 1803) has been documented in the Czech Republic for the first time, in the Horní Počernice district of Prague. This locality in general, and the patches with the occurrence of M. cantiana in particular, can be characterized as xeric, predominantly grassy, habitats, where the species lives in very abundant populations accompanied by common snail species as well as several other non-native species.

\section{Acknowledgements}

We are grateful to J. Šašek for the identification of plant species, and to M. Horsák for photographing the Monacha cantiana shell. We also thank to B. Páll-Gergely for useful comments. This study was supported by the research project of National Museum in Prague no. MK00002327201, by the project of the Grant Agency of Charles University GA UK no. 63407 , and by the research project of the Institute of Geology AS CR no. AV0Z30130516.

\section{References}

Aubry S., Labaune C., Magnin F., Roche P. \& Kiss L., 2006: Active and passive dispersal of an invading land snail in Mediterranean France. - Journal of Animal Ecology, 75: 802-813.

BenKe M. \& RenKer C., 2005: Vorkommen von Monacha cartusiana (O.F. Müller, 1774) und Cernuella neglecta (Draparnaud, 1805) im Stadtgebiet von Leipzig (Sachsen). - Malakologische Abhandlungen, 23: 109-115.

Chatfield J.E., 1968: The life history of the Helicid snail Monacha cantiana (Montagu), with references also to M. cartusiana (Müller). - Proceedings of the Malacological Society of London, 38: 233-245.

Fechter R. \& Falkner G., 1990: Weichtiere. - Mosaik Verlag, München, $287 \mathrm{pp}$.

Fischer W. \& DUdA M., 2004: Beiträge zur Kenntnis der Molluskenfauna Österreichs VII. Cernuella virgata (da Costa 1778), neu für die Molluskenfauna Wiens, sowie Bemerkungen zur Ausbreitung von Monacha cantiana (Montagu 1803), Cernuella neglecta (Draparnaud 1805), Hygromia cinctella (Draparnaud 1801) und Cornu aspersus (O.F.Müller 1774) in Niederösterreich und Wien (Mollusca: Gastropoda). - Nachrichtenblatt der Ersten Vorarlberger Malakologischen Gesellschaft, 12: 10-14.

Germain L., 1930: Mollusques terrestres et fluviatiles (première partie). - Faune de France, 21: 1-477.

Grossu A.V., 1983: Gastropoda Romaniae 4. Ordo Styllomatophora, Suprafam.: Arionacea, Zonitacea, Ariophantacea si Helicacea. - Editura Litera, Bucuresti, 564 pp. (in Romanian with English extended summary).

HudEC V., 1954: Rozšíření hlemýždě Theba cartusiana na jižní
Moravě [Distribution of snail Theba cartusiana in Southern Moravia]. - Vesmír, 33 (9): 314-315 (in Czech).

JUŘIČKovÁ L., 1998: Měkkýši Hradce Králové [Mollusca of Hradec Králové, East Bohemia, Czech Republic]. - Acta Musei Reginahradecensis S.A., 26: 101-172 (in Czech).

JUŘIČKOVÁ L., 2006: Mollusca (Partim) - Suchozemští plži. [Mollusca (Part) - Terrestrial gastropods] - In: Nepůvodní druhy ve fauně a flóře České republiky [Alien species of fauna and flora of the Czech Republic], MLíkovskÝ J. \& STÝBlo P. (eds) ČSOP, Praha, pp. 214-215 (in Czech).

JuŘIČKOVÁ L. \& KAPOUNEK F., 2009: Helix (Cornu) aspersa (O.F. Müller, 1774) (Gastropoda: Helicidae) in the Czech Republic. - Malacologica Bohemoslovaca, 8: 53-55.

Kerney M.P., Cameron R.A.D. \& Jungbluth J.H., 1983: Die Landschnecken Nord- und Mitteleuropas. - Verlag Paul Parey, Hamburg und Berlin, 384 pp.

Kolouch L.R., 2005: Další lokality tmavoretky bělavé [New evidence of the occurrence of the Carthusian snail]. - Živa, 53 (3): 123 (in Czech).

LiLl K., 2002 : Monacha cantiana (Montagu, 1803) in Magdeburg - Erstnachweis für Sachsen-Anhalt (Gastropoda: Stylommatophora: Hygromiidae). - Malakologische Abhandlungen, 20: $345-346$.

LožEK V., 1956: Klíč československých měkkýšů [Key to Czechoslovak molluscs]. - SAV, Bratislava, 437 pp. (in Czech).

LožEK V., 1999: Jihoevropský plž Monacha cartusiana v Českém Krasu [South European Gastropod Carthusian Snail in the Bohemian Karst]. - Živa, 47 (4): 175 (in Czech).

Manganelli G., Bodon M., Favilli L. \& Giusti F., 1995: Fascicolo 16. Gastropoda Pulmonata. - In: Checklist delle specie della fauna italiana, Minelli A., Ruffo S. \& La Posta S. (eds), pp. $1-60$.

MAŇAS M., 2002: Měkkýši (Gastropoda, Bivalvia) černovírského slatiniště u Olomouce [Molluscs (Gastropoda, Bivalvia) of Černovír fens near Olomouc]. - URL: http://mollusca.wz.cz/ malakologie/Cernovir.pdf ; version 05/22/2005 (in Czech).

Míkovcová A. \& JuřičKová L., 2008: Hledá se tmavoretka bělavá [The Carthusian snail wanted]. - Živa, 56 (2): 73 (in Czech).

Novák J. \& NovÁk M., 2009: Dvě nové lokality tmavoretky bělavé Monacha cartusiana (O.F. Müller, 1774) na Moravě [Two new localities of Monacha cartusiana (O.F. Müller, 1774) in Moravia, Czech Republic]. - Malacologica Bohemoslovaca, 8: 29-30 (in Czech).

Pech P. \& Pechová H., 2009: Monacha cartusiana (Gastropoda: Hygromiidae) in South Bohemia. - Malacologica Bohemoslovaca, 8: 28.

Roques A., Rabitsch W., Rasplus J.-Y., Lopez-Vaamonde C., Nentwing W. \& Kenis M., 2009: Alien Terrestrial Invertebrates of Europe. - In: Handbook of Alien Species in Europe, DrAKE J.A. (ed.), vol. 3, pp. 63-79.

URBÁNeK L., 1968: Hlemýžd' Monacha cartusiana (O.F. Müller) v Čechách [Snail Monacha cartusiana (O.F. Müller) in Bohemia]. - Časopis Národního muzea, odd. přír., 137 (3/4): 114 (in Czech). 